Proc. Estonian Acad. Sci. Geol., 2006, 55, 2, 95-108

\title{
Ordovician timescale in Estonia: recent developments
}

\author{
Jaak Nõlvak, Olle Hints, and Peep Männik \\ Institute of Geology at Tallinn University of Technology, Estonia pst. 7, 10143 Tallinn, Estonia;
} nolvak@gi.ee,olle@gi.ee,mannik@gi.ee

Received 8 February 2006, in revised form 5 April 2006

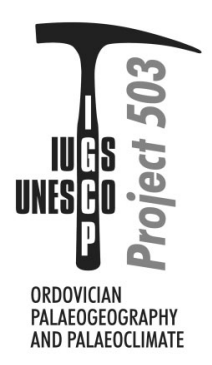

Abstract. Over 150 years of progress in the Ordovician geology and stratigraphy of Estonia has resulted in one of the most precise Ordovician timescales in the world. In this paper, an up-to-date version of the Ordovician timescale of Estonia is provided. Recent developments in graptolite, chitinozoan, and conodont biostratigraphy, and the correlation with the global standard are briefly commented upon. Application of the regional subseries rank is discussed and two new names are proposed: "Vinni" for the upper subseries of the Viru Series, and "Atla" for the upper subseries of the Harju Series.

Key words: stratigraphy, timescale, Ordovician, graptolites, chitinozoans, conodonts, Estonia.

\section{INTRODUCTION}

Studies of Ordovician rocks and fossils in Estonia started in the early 19th century and have resulted in one of the most detailed regional timescales in the world with use not just in Estonia but also in several neighbouring areas (Männil 1966, 1987; Männil \& Meidla 1994 and references therein; Jaanusson 1995). The Estonian time-stratigraphic nomenclature currently serves as a proxy for Baltoscandia and the entire Baltica terrane (Cooper \& Sadler 2004; Webby et al. 2004).

For over 150 years, the succession of the British series and stages had been taken as the de facto global standard in Ordovician stratigraphy. In recent decades, however, much effort has been put into building a more universal global timescale. A tripartite series-level subdivision of the Ordovician System has been agreed upon and seven global stages already are, or will soon be, defined by global stratotype sections and points (Finney 2005 and references therein). Indeed, these developments have raised several questions regarding the future status and usage of various regional stratigraphical schemes that currently exist worldwide. In the 1990s the Ordovician of the historical type area in the British Isles was also revised 
to overcome various problems with uneven subdivision and imprecise definition of series and stages, with particular emphasis on their boundaries and boundary stratotypes (Fortey et al. 1995, 2000).

In this paper we aim to provide an up-to-date compilation of the Ordovician timescale as it is used in Estonia. Although previous compilations exist (e.g., Männil 1990; Hints et al. 1993; Männil \& Meidla 1994; Nõlvak 1997; Meidla \& Ainsaar 2004), they need modernization. We also propose some nomenclatural improvements to fill gaps in the subseries rank and briefly discuss some recent developments in biostratigraphy and correlation with the international timescale. It is beyond the scope of this paper to cover various aspects of stable isotope stratigraphy (see Kaljo et al. 2004, and Kaljo \& Martma 2005 for review), and correlation of rock units (e.g., Ainsaar \& Meidla 2001; Hints, L. et al. 2005).

\section{COMMENTS ON THE UPDATED REGIONAL TIMESCALE}

\section{Base of the Ordovician and base of the Öland Regional Series}

Puura \& Viira $(1999,2004)$ subdivided the lowermost Ordovician stage in Baltoscandia, the Pakerort Stage, into two units, the Vihula and Karepa substages, and provided boundary stratotypes and primary correlation criteria for their boundaries (appearance of the conodonts Cordylodus andresi Viira \& Sergeeva and Cordylodus lindstromi Druce \& Jones, respectively).

The internationally accepted lower boundary of the Ordovician System is defined by the appearance of Iapetognathus fluctivagus Nicoll, Miller, Nowlan, Repetski \& Ethington in the Green Point section, Newfoundland (Cooper et al. 2001). The closest level to the global boundary widely traceable in Baltoscandia is that of the appearance of Cordylodus lindstromi (i.e., the base of the Karepa Substage). Therefore the base of the Pakerort Stage, as well as the base of the Öland Series, lies below the lower boundary of the Ordovician System, within the topmost Cambrian. Hence, neither the Pakerort Stage nor the Öland Series can strictly be taken as subdivisions of the Ordovician. This example clearly illustrates the independence of regional and global stratigraphical hierarchies.

Note that the Latin-spelled "Oeland", which has been used in many regional stratigraphical charts (e.g., Männil 1990; Männil \& Meidla 1994; Nõlvak 1997; Meidla \& Ainsaar 2004), is obsolete and should be abandoned in favour of "Öland".

\section{Correlation of the Sixth Global Stage ("Katyan")}

In 2005 the Subcommission on Ordovician Stratigraphy approved the GSSP for the Sixth Global Stage of the Ordovician System in a succession of black shales and chert along Black Knob Ridge in southeastern Oklahoma, USA, as suggested by Goldman et al. (2005). The boundary level coincides with the first appearance of the graptolite Diplacanthograptus caudatus (Lapworth), which is known from 
Australasia, Eastern North America, South Central USA, Scotland, Newfoundland (Goldman 2003), but not from the East Baltic. The global boundary lies between two important geochemical markers, the Millbrig K-bentonite and the Guttenberg (GICE) carbon isotope excursion (Goldman et al. 2005). The Millbrig K-bentonite has been correlated with the Baltoscandian Kinnekulle K-bentonite, which marks the base of the Keila Stage (Bergström et al. 1995). This correlates the base of the Keila Stage with the base of the North American Chatfieldian Stage and with $5 \mathrm{~b} / 5 \mathrm{c}$ boundary of Webby et al. (2004). The Guttenberg carbon isotope excursion (Salzman et al. 2003), on the other hand, appears to be correlative with the midCaradocian excursion in Baltoscandia (Ainsaar et al. 1999, 2004; Kaljo et al. 2004; Martma 2005). The latter excursion occurs in mid-Keila beds of southern Estonia and Latvia (Kaljo et al. 2004, fig. 4; Nõlvak 2005), but has not been recorded in North Estonia, where the sequence is less complete (Kaljo et al. 1999, fig. 2; Kaljo et al. 2004, figs 3, 4).

The chitinozoan fauna recovered from the GSSP section and a supplementary limestone section in Oklahoma supports correlation with the Baltic Spinachitina cervicornis Zone (Goldman et al. 2005). Thus, the base of the Sixth Stage of the Ordovician System correlates with the lower to middle part of the Keila Stage in Baltoscandia, and is in close proximity to the foliaceous/clingani graptolite zonal boundary.

\section{Atla and Vinni regional subseries}

In recent years questions have arisen about whether the current stage-level subdivision of the Ordovician used in Estonia is too precise or, conversely, too general. Nielsen et al. (2004) proposed to reduce the rank of some stages to substages, resulting in 8 or 10 stages instead of 18 , in order to enhance the usability of the regional timescale.

The correlation of several Estonian stages can be difficult outside the North Estonian outcrop area, and hence, Jaanusson (1995) established a new unit, the Haljala Stage, to incorporate the Idavere and Jõhvi stages as substages. This proposal is now followed in Estonia, but not in NW Russia, where the stage rank for the Idavere and Jõhvi units is still considered more appropriate (Dronov 2005).

The correlation problems are partly due to still insufficient biostratigraphical data, and are mainly connected with correlations between shallow and deeper shelf successions. The historical and geological background, particularly the fact that most stages were defined in the North Estonian outcrop area rich in stratigraphical gaps, and imprecise boundary definitions also contribute to these difficulties (see Hints et al. 1995). Admittedly, decreasing the resolution of the regional timescale could avoid some correlation problems, but it would not improve any of the existing tie points.

Moreover, it appears that a set of regional units very similar in number and content to those suggested by Nielsen et al. (2004) already exist, although not in the stage rank - the regional subseries. In ascending order these are (Fig. 1): Iru (Luha 1940), Ontika (Kaljo et al. 1958), Purtse (Rõõmusoks 1956), Kurna 


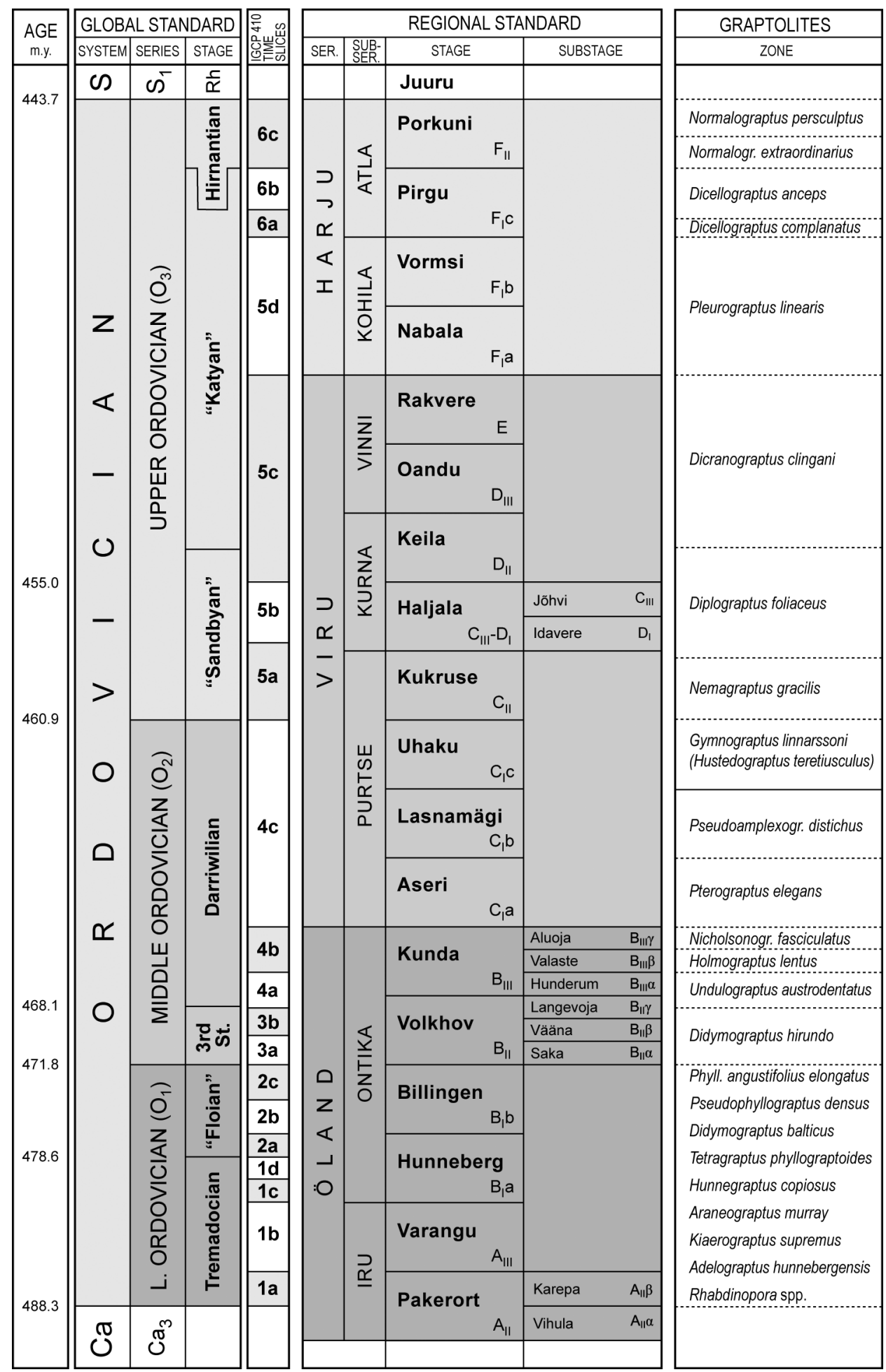

Fig. 1. For explanation see p. 100. 


\begin{tabular}{|c|c|c|c|c|}
\hline 岁 & CHITIN & ZOANS & CONO & DONTS \\
\hline$\frac{1}{\infty}$ & ZONE & SUBZONE & ZONE & SUBZONE \\
\hline & Conochitina scabra & & Noixodontus fauna & \\
\hline 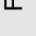 & Spinachitina taugourdeaui & & & \\
\hline & Belonechitina gamachiana & & & \\
\hline $4^{0}$ & $\begin{array}{l}\text { Tanuchitina anticostiensis } \\
\text { Conochitina rugata }\end{array}$ & & Amorphognathus ordovicicus & \\
\hline & Tanuchitin a berastroemi & Acanthochitina barbata & & \\
\hline & & & & \\
\hline & & & ? & \\
\hline 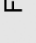 & & Armoricochitina reticulifera & & \\
\hline ш & & Cyathochitina angusta & Amorphognathus superbus & \\
\hline ఏ & & Ancyrochitina sp. n. 1 & Amorphognathus ventilatus & \\
\hline$\square=$ & Spinachitina cervicornis & & ? & \\
\hline & & Angochitina multiplex & & \\
\hline جִ & \begin{tabular}{|l} 
Belonechitina hirsuta \\
Lagenochitina dalbyensis
\end{tabular} & & & \\
\hline$\overline{\bar{O}}$ & $\begin{array}{l}\text { Angochitina curvata } \\
\text { = Armoricochitina granulifera } \\
\end{array}$ & & Amprnhonathus thanerencic & $\begin{array}{l}\text { Baltoniodus alobatus } \\
\text { Baltoniodus gerdae }\end{array}$ \\
\hline$\overline{0}$ & & Eisenackitina rhenana & 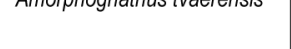 & Baltoniodus variabilis \\
\hline & Laufeldochitina stentor & & & $\begin{array}{l}\text { Amorphognathus inaequalis } \\
\text { Sagittodontina kielcensis }\end{array}$ \\
\hline & & Upper Conochitina tuberculata & rygoaus anserinus & \begin{tabular}{|l} 
Eoplacogn. lindstroemi \\
\end{tabular} \\
\hline 0 & & Lower Conochitina tuberculata & & $\begin{array}{l}\text { - Eoplacogn. protoramosus } \\
\text { Eoplacognathus robustus }\end{array}$ \\
\hline & & Conochitina clavaherculi & Pygodus serra & Eoplacognathus reclinatus \\
\hline & & Cyathochitina sebyensis & & Eoplacognathus foliaceous \\
\hline$\tilde{\sigma}^{\sigma}$ & & & Eoplacognathus suecicus & \\
\hline ळ & Cyathochitina regnelli & & Eoplacogn. pseudoplanus & \\
\hline & Conochitina cucumis & & $\begin{array}{l}\text { Lenodus variabilis } \\
\text { Baltoniodus norrlandicus }\end{array}$ & $\begin{array}{l}\text { Lenodus antivariabilis } \\
\text { Trapezogn. quadrangulum }\end{array}$ \\
\hline $\bar{m}$ & Cunthochitina nrimitiva & & $\begin{array}{l}\text { Paroistodus originalis } \\
\text { - Baltoniodus navis } \\
\text { Baltoniodus triangularis } \\
\text { Trapezognathus diprion } \\
\text { Oepikodus evae } \\
\end{array}$ & \\
\hline & & & Prioniodus elegans & \\
\hline$\frac{\pi}{\infty}$ & & & Paroistodus proteus & \\
\hline & Lagenochitina destombesi & & & \\
\hline$\overline{4}$ & & & Paltodus deltifer & \\
\hline$<$ & & & $\begin{array}{l}\text { Cordylodus angulatus } \\
\text { - Cordylodus lindstromi } \\
\text { - Cordylodus intermedius } \\
\text { - Cordylodus proavus } \\
\text { Cordylodus andresi }\end{array}$ & \\
\hline
\end{tabular}

Fig. 1. Continued. 
(Männil 1958), and Kohila (Rõõmusoks 1956). Historically these units have been termed as "jarus" (Russian яpyc denoting a rank between series and stages), "regional jarus", superstage or subseries. The latter category has obviously the widest acceptance and is consistently used in all recent contributions (Männil 1990; Hints et al. 1993; Männil \& Meidla 1994; Meidla \& Ainsaar 2004). The currently named subseries cover the entire timespan of the Öland Series but the uppermost subseries of the Viru Series and upper subseries of the Harju Series have been referred to as "unnamed" so far.

To complete the regional subseries classification, we propose two new names, Vinni for the third subseries of the Viru Series, and Atla for the second subseries of the Harju Series. The name Vinni comes from the Vinni (T-112) borehole that has been selected as the hypostratotype section for the Rakvere Stage (see Põlma et al. 1988). This drill core is deposited at the Institute of Geology at Tallinn University of Technology. A detailed description of the section is provided by Põlma et al. (1988). The Atla subseries is designated after the Atla River that runs near the Pirgu Manor and on the banks of which the rocks of the Pirgu Age are exposed (e.g., Meidla 1996). The lower boundaries of these, and also other subseries (and series) are, indeed, defined as those of the lowest stage they contain. Providing appropriate definitions for stages is, however, beyond the scope of this report.

\section{Graptolite biostratigraphy}

Gymnograptus linnarssoni (Hustedograptus teretiusculus) Zone. Männil (1976) formally proposed using the range of G. linnarssoni for a local (Baltoscandian) biozone, and later in the regional stratigraphical scheme the base of the Uhaku Stage was defined by the FAD of G. linnarssoni (Männil 1987). This level coincides approximately with the boundary between the Eoplacognathus reclinatus and E. robustus conodont subzones of the Pygodus serra Zone. Recently Hustedograptus teretiusculus was identified from Latvia (Kandava-25 section, interval 944.1-953.1 m, D. Goldman, pers. comm. 2006), appearing together with G. linnarssoni. Since the latter species is more common in carbonate succession, including the stratotype area in northern Estonia, it is reasonable to replace the $H$. teretiusculus Zone with the G. linnarssoni Zone for regional use. This level is close to the first appearance of Dicellograptus, however, graptolites are extremely rare or absent in the main part of the Uhaku Stage. The upper limit of this zone is drawn at the appearance of Nemagraptus gracilis. In the Fågelsång area, southern Sweden, where the GSSP for the Fifth Global Stage ("Sandbyan" by Bergström et al. 2005) is defined, G. linnarssoni disappears just below the appearance of $N$. gracilis (Bergström et al. 2000).

Fig. 1. Ordovician regional timescale, its correlation with the international standard and time slices introduced by Webby et al. (2004), and graptolite, chitinozoan, and conodont biozonations. Absolute ages are after Cooper \& Sadler (2004). For full explanation and further references see text. Note that global and regional scales as well as biozonal schemes are drawn separately, emphasizing their independence. The global stage names given in quotation marks are those proposed by Bergström et al. (2005). 
Nemagraptus gracilis Zone. Nemagraptid graptolites are a particularly important fossil group for Ordovician biostratigraphy. The GSSP for the Upper Ordovician Series and for the Fifth Global Stage ("Sandbyan") located in the Fågelsång area, southern Sweden, was chosen to coincide with the appearance (FAD) of Nemagraptus gracilis (Bergström et al. 2000). Accordingly, this cosmopolitan graptolite is used as the main correlation criterion for the boundary of the Fifth Stage as well as the Upper Ordovician Series worldwide (e.g., Finney \& Bergström 1986; Bergström et al. 2000).

Nemagraptus gracilis is common in the black shale facies of Scania, southern Sweden. In carbonate successions of the eastern Baltic area, however, its finds are very rare. Recent finds of $N$. gracilis and re-identifications of older collections from Estonian and Latvian sections are summarized by Nõlvak \& Goldman (2004). All these specimens of $N$. gracilis come from the upper part of the Kukruse Stage, and are in the upper portion of the Eisenackitina rhenana chitinozoan Subzone below the Armoricochitina granulifera Zone (in the lowermost Haljala Stage). According to Nõlvak \& Grahn (1993), the base of the A. granulifera Zone lies above the base of the Diplograptus foliaceous Zone. Based on the graptolite ranges in the Kandava-25 core (Latvia), it is likely that the uppermost Kukruse interval is the D. foliaceous Zone in age (D. Goldman, pers. comm.). The exact level of the base of the Upper Ordovician in Estonia is nevertheless debatable and some disagreements between different biozonations are yet to be resolved (see discussion in Hints, O. et al. 2005).

\section{Chitinozoan biostratigraphy}

The chitinozoan zonation, formally defined for the entire Baltoscandia by Nõlvak \& Grahn (1993) and later emended by Nõlvak (1999), has good correlative value and is widely used in Estonia and elsewhere in Baltoscandia. Below some nomenclatural aspects and new data are discussed.

Lower and Upper Conochitina tuberculata subzones. The C. tuberculata Subzone was initially defined as spanning the Laufeldochitina striata and L. stentor zone boundary (Nõlvak \& Grahn 1993). The position of this subzone, however, is contrary to the common practice of defining subzones, which are to be subdivisions of a particular zone rather than units of a separate succession. To overcome this problem, the former C. tuberculata Subzone is divided into two parts. The Lower C. tuberculata Subzone in the upper part of the Laufeldochitina striata Zone is defined as ranging from the appearance of $C$.tuberculata to the appearance of L. stentor. The Upper C.tuberculata Subzone in the lower part of the Laufeldochitina stentor Zone is defined by the appearance of L. stentor and disappearance of the nominal species.

Fungochitina spinifera Zone. The taxonomic problems with the key species of the Fungochitina fungiformis Zone complicate the use of this zone, as noted by Nõlvak $(2001,2005)$ in the Valga (10) and Mehikoorma (421) sections. Originally, 
Nõlvak \& Grahn (1993) defined this zone as the total range of $F$. fungiformis Eisenack and did not distinguish the subspecies $F$. fungiformis fungiformis Eisenack and $F$. fungiformis spinifera Eisenack. However, in the revision of Fungochitina by Paris et al. (1999) these subspecies were elevated to species rank, and assigned to different genera: the glabrous fungiformis to Saharochitina and spinifera to Fungochitina. Therefore the name of this zone needs to be changed from Fungochitina fungiformis to $F$. spinifera.

Tanuchitina anticostiensis Zone. This zone was first used in the Estonian sections where the Pirgu succession is stratigraphically more complete (Nõlvak 2002, fig. 4; see distribution of chitinozoans in the Kardla section in Brenchley et al. 2003, fig. 10). This zone is present above the Conochitina rugata Zone and below the Belonechitina gamachiana Zone and defined as an interval between the first appearance of $T$. anticostiensis Achab and the first appearance of B. gamachiana (Achab). However, the T. anticostiensis Zone has limited vertical and restricted spatial distribution (see Hints, L. et al. 2005, fig. 2), and needs additional study.

Belonechitina gamachiana Zone. This zone was originally defined in Baltoscandia by Nõlvak (1999) as corresponding to an interval between the Conochitina rugata (Nõlvak) and Spinachitina taugourdeaui (Eisenack) zones in the uppermost Pirgu Stage.

The definition of the Baltoscandian C. rugata Zone needs to be updated: it corresponds to the interval between the first occurrence of the nominal species and the appearance of T. anticostiensis. Hence, the B. gamachiana Zone is defined as an interval from its appearance to the appearance of $S$. taugourdeaui.

For long-distance correlations it is important to note that the succession of species (and zones) T. anticostiensis-B. gamachiana-S. taugourdeaui occurs also in the same order on Anticosti Island (Achab 1989). The B. gamachiana Zone is of late Pirgu age in the East Baltic sections, and not of Porkuni age as mistakenly indicated by Webby et al. (2004, fig. 2.2).

\section{Conodont biostratigraphy}

Conodont studies have revealed that faunas from the Öland Series in Estonia show great similarity to those of Swedish sections. Accordingly, there is a good correspondence between conodont zonations of these areas, and most of the zones distinguished in Sweden can be recognized in Estonia (Viira et al. 2001). Recent investigations of conodont successions in the upper Middle and Upper Ordovician strata of the Valga (10), Ruhnu (500), and Mehikoorma (421) core sections resulted in some revision of the conodont zonation, which has allowed for a more detailed biostratigraphy in some intervals (Männik 2001, 2003; Männik \& Viira 2005).

Pygodus anserinus Zone. The $P$. anserinus Zone was originally described by Bergström (1971) and was subdivided into the Lower and Upper subzones. The boundary between these subzones was defined as the level at which the evolutionary transition of Baltoniodus prevariabilis (Fåhraeus) into B. variabilis (Bergström) 
takes place. Later, based on the suggestion by Dzik (1978) that Sagittodontina kielcensis (Dzik) is replaced by Amorhognathus inaequalis Rhodes at the same level, Bergström (1983) proposed to rename these subzones, respectively, as the $S$. kielcensis and A. inaequalis subzones. However, because these two taxa usually occur sporadically in the sections, the boundary between the subzones can be best identified on the changes in the Baltoniodus lineage.

In Estonia, S. kielcensis appears in the upper Pygodus serra Zone (in the Eoplacognathus lindstroemi Subzone) and reaches the middle part of the S. kielcensis Subzone of the P. anserinus Zone (e.g., Männik 2003; Männik \& Viira 2005). Amorphognathus inaequalis has been found in the upper part of the $A$. inaequalis Subzone of the same P. anserinus Zone. The boundary between the $S$. kielcensis and A. inaequalis subzones (= the level of appearance of B. variabilis) in Estonia lies probably in the lowermost part (coincides with the base?) of the Kukruse Stage. However, it should be noted that the oldest specimens of the Amorphognathus lineage are usually very rare and therefore species-level identifications may be complicated (see below).

Amorphognathus tvaerensis Zone. The zone was defined by Bergström (1971) as an interval between the first appearance of $A$. tvaerensis and the appearance of its descendant, $A$. superbus Rhodes. The A. tvaerensis Zone is further subdivided into three subzones (in ascending order): Baltoniodus variabilis, B. gerdae, and B. alobatus.

The A.tvaerensis Zone and its subzones are well represented in Estonia. The base of the zone lies in the lower part of the Kukruse Stage. According to Viira et al. (2006), A. tvaerensis appears just above the Uhaku-Kukruse boundary in northern Estonia. The first reliably identified specimens come, nevertheless, from slightly higher strata, from the upper part of the Kiviõli Member. Amorphognathus tvaerensis disappears fairly close to the Idavere and Jõhvi substage boundary.

The range of $A$. tvaerensis is followed by an interval where Amorphognathus is missing or too rare to be found. This interval corresponds approximately to the upper Haljala and Keila stages and may be related to the Mid-Caradoc Event (Männik 2004). The lineage reappears in the Oandu Stage, represented by A. ventilatus Ferreti \& Barnes (Männik 2003; Männik \& Viira 2005). Considering our new data, the A. tvaerensis Zone is treated here only as the total range of the nominal species, covering a shorter interval than shown in previous compilations.

It is noteworthy that B. alobatus (Bergström) disappears after A. tvaerensis, providing another level for regional correlation. The top of the B. alobatus Subzone, however, is also set by the disappearance of $A$. tvaerensis.

Amorphognathus ventilatus Zone. Dzik (1999) established an interval between the ranges (zones) of $A$. tvaerensis and A. superbus, which could be recognized by the presence of $A$. ventilatus. In the Estonian sequence, $A$. ventilatus appears in the lowermost Oandu Stage after the gap in the Amorphognathus range (see Fig. 1, and Männik \& Viira 2005).

The upper boundary of the zone is marked by the appearance of $A$. superbus. In Estonia, the A. ventilatus Zone corresponds to the main part of the Oandu Stage. 
In earlier regional composites, the interval that coincided with the $A$. ventilatus Zone was correlated with the Ozarkodina aff. rhodesi-Icriodella cf. superba Zone (Viira 1974).

Amorphognathus ordovicicus Zone. The zone was defined by Bergström (1971) as corresponding to the total range of A. ordovicicus (Branson \& Mehl), which was considered to be the last member in the evolutionary lineage of Amorphognathus, a taxon that became extinct at the Ordovician-Silurian boundary. However, as Dzik (1999) shows, A. ordovicicus is not the last species in the lineage but is followed by $A$. duftonus Rhodes, a species that has not been recovered from Estonian sections.

The position of the lower boundary of the zone is also somewhat problematic. Männik (1992) noted that A. ordovicicus appears in the lowermost Vormsi Stage in Estonia. In the upper part of the Nabala Stage, a single M element of Amorphognathus identical to that of Amorphognathus sp. n. Dzik was recovered from the Mehikoorma (421) section (Männik \& Viira 2005). This may indicate that the lowermost part of the A. ordovicicus Zone in the Mehikoorma (421) section described by Männik \& Viira (2005) and corresponding to the upper Nabala Stage is, in reality, an equivalent to the Amorphognathus sp. n. interval sensu Dzik (1999). For this reason the lower boundary of the A. ordovicicus Zone is tentatively drawn near the base of the Vormsi Stage (Fig. 1).

Noixodontus fauna. The uppermost Ordovician conodont fauna of the Porkuni Stage in South Estonian sections, excluding its lowermost part - the Bernati Member, differs considerably from that of the underlying strata with A. ordovicicus (Männik 2001, 2003). This very poor but distinctive conodont fauna is dominated by Noixodontus girardeauensis (Satterfield), whilst Amorphognathus is missing or extremely rare and represented by poorly preserved fragments. This specific assemblage co-occurs with the Hirnantia Fauna and is considered to have a significant potential for regional correlations, but further data are needed to formally propose a corresponding biozone.

\section{CONCLUSIONS}

Regional units are useful only if they provide better resolution for local geological studies than the units of the global timescale. If the latter were precise enough, the regional chronostratigraphic scale would be unnecessary. The global scale is, in most parts of the Ordovician, less precise than the current regional scheme for local stratigraphic studies. Thus, we believe that instead of abandoning regional chronostratigraphy or decreasing its resolution, more effort should be put into finding new information and improving the existing criteria for intraand interregional correlations for which there is a great potential in bio- and chemostratigraphy. The role of chronostratigraphy, however, should not be overestimated in regional stratigraphy, particularly in cases where appropriate biostratigraphical and lithostratigraphical units can be used. 


\section{ACKNOWLEDGEMENTS}

The authors are grateful to Dimitri Kaljo for invaluable comments and improvements. We would like to thank the referees, Daniel Goldman, Dayton, and Tõnu Meidla, Tartu. This study is a contribution to IGCP Project 503 and was supported by the Estonian Science Foundation grants Nos 5406, 5920, 5922, and 6127.

\section{REFERENCES}

Achab, A. 1989. Ordovician chitinozoan zonation of Quebec and western Newfoundland. J. Paleontol., 63, 14-24.

Ainsaar, L. \& Meidla, T. 2001. Facies and stratigraphy of the middle Caradoc mixed siliciclasticcarbonate sediments in eastern Baltoscandia. Proc. Estonian Acad. Sci. Geol., 50, 5-23.

Ainsaar, L., Meidla, T. \& Martma, T. 1999. Evidence for a widespread carbon isotopic event associated with late Middle Ordovician sedimentological and faunal changes in Estonia. Geol. Mag., 136, 49-62.

Ainsaar, L., Meidla, T. \& Martma, T. 2004. The Middle Caradoc Facies and Faunal Turnover in the Late Ordovician Baltoscandian palaeobasin. Palaeogeogr. Palaeoclimatol. Palaeoecol., 210, $119-133$.

Bergström, S. M. 1971. Conodont biostratigraphy of the Middle and Upper Ordovician in Europe and eastern North America. Geol. Soc. Amer. Mem., 127, 83-157.

Bergström, S. M. 1983. Biogeography, evolutionary relationships, and biostratigraphic significance of Ordovician platform conodonts. Fossils Strata, 15, 35-58.

Bergström, S. M., Huff, W. D., Kolata, D. R. \& Bauert, H. 1995. Nomenclature, stratigraphy, chemical fingerprinting and areal distribution of some Middle Ordovician K-bentonites in Baltoscandia. GFF, 117, 1-13.

Bergström, S. M., Finney, S. C., Chen, X., Pålsson, C., Wang, Z. H. \& Grahn, Y. 2000. A proposed global boundary stratotype for the base of the Upper Series of the Ordovician System: the Fågelsång section, Scania, southern Sweden. Episodes, 23, 102-109.

Bergström, S. M., Finney, S. C., Chen, X., Goldman, D. \& Leslie, S. A. 2005. Proposed names for three Ordovician global stages. http://www.ordovician.cn/discussionsshowtopic. asp? $\mathrm{id}=252 \&$ cateid=13\& subcateid=26, accessed January 2006.

Brenchley, P. J., Carden, G. A., Hints, L., Kaljo, D., Marshall, J. D., Martma, T., Meidla, T. \& Nõlvak, J. 2003. High-resolution stable isotope stratigraphy of Upper Ordovician sequences: constraints on the timing of bioevents and environmental changes associated with mass extinction and glaciation. Geol. Soc. Amer. Bull., 115, 89-104.

Cooper, R. A. \& Sadler, P. M. 2004. The Ordovician Period. In A Geologic Time Scale 2004 (Gradstein, F. M., Ogg, J. G., Smith, A. G., Agterberg, F. P., Bleeker, W. et al., eds), pp. 165-187. Cambridge University Press.

Cooper, R. A., Nowlan, G. S. \& Williams, S. H. 2001. Global Stratotype Section and Point for base of the Ordovician System. Episodes, 24, 19-28.

Dronov, A. 2005. Ordovician of the St. Petersburg Region. In 6th Baltic Stratigraphical Conference. Cambrian and Ordovician of St. Petersburg Region. Guidebook of the Pre-conference Field Trip (Dronov, A., Tolmacheva, T., Raevskaya, E. \& Nestell, M., eds), pp. 5-9. St. Petersburg State University, VSEGEI, St. Petersburg.

Dzik, J. 1978. Conodont biostratigraphy and plaeogeographical relations of the Ordovician Mojcza Limestone (Holy Cross Mts., Poland). Acta Palaeontol. Polonica, 23, 51-72.

Dzik, J. 1999. Evolution of the Late Ordovician high-latitude conodonts and dating of Gondwana glaciations. Boll. Soc. Paleontol. Italiana, 37, 237-253. 
Finney, C. F. \& Bergström, S. M. 1986. Biostratigraphy of the Ordovician Nemagraptus gracilis Zone. In Palaeoecology and Biostratigraphy of Graptolites. (Hughes, C. P. \& Rickards, R. B., eds). Geol. Soc. Spec. Publ., 20, 47-59.

Finney, S. 2005. Global Series and Stages for the Ordovician System: a progress report. Geol. Acta, 3, 309-316.

Fortey, R. A., Harper, D. A. T., Ingham, J. K., Owen, A. W. \& Rushton, A. W. A. 1995. A revision of Ordovician series and stages from the historical type area. Geol. Mag., 132, 15-30.

Fortey, R. A., Harper, D. A. T., Ingham, J. K., Owen, A. W., Parkes, M. A., Rushton, A. W. A. \& Woodcock, N. H. 2000. A revised correlation of Ordovician rocks in the British Isles. Geol. Soc. London Spec. Rep., 24, 1-83.

Goldman, D. 2003. The Diplacanthograptus caudatus Zone: a proposal for a new, globally recognizable, Upper Ordovician graptolite zone. In Ordovician from the Andes (Albanesi, G. L., Beresi, M. S. \& Peralta, S. H., eds). INSUGEO Ser. Correl. Geol., 17, 65-70.

Goldman, D., Leslie, S. A., Nõlvak, J. \& Young, S. 2005. The Black Knob Ridge Section, Southeastern Oklahoma, USA: A Possible Global Stratotype-Section and Point (GSSP) for the Base of the Middle Stage of the Upper Ordovician Series. Revised Report for the ISOS GSSP discussion site, http://www.stratigraphy.org/BKR.pdf.

Hints, L., Meidla, T., Gailite, L.-I. \& Sarv, L. 1993. Catalogue of Ordovician Stratigraphical Units and Stratotypes of Estonia and Latvia. Institute of Geology, Estonian Academy of Sciences, Tallinn.

Hints, L., Meidla, T. \& Nõlvak, J. 1995. Ordovician sequences of the East European Platform. Geologija, 1994, 17, 58-63.

Hints, L., Oraspõld, A. \& Nõlvak, J. 2005. Upper Ordovician Pirgu Regional Stage in the East Baltic: lithostratigraphy, biozonation, and correlation. Proc. Estonian Acad. Sci. Geol., 54, 225-259.

Hints, O., Nõlvak, J. \& Viira, V. 2005. Microfossil dynamics and biostratigraphy in the UhakuKukruse boundary interval (Ordovician) of NE Estonia. In The Sixth Baltic Stratigraphical Conference, August 23-25, St. Petersburg, Russia. Abstracts (Koren, T., Evdokimova, I. \& Tolmacheva, T., eds), pp. 40-42. VSEGEI, St. Petersburg State University, St. Petersburg.

Jaanusson, V. 1995. Confacies differentiation and upper Middle Ordovician correlation in the Baltoscandian basin. Proc. Estonian Acad. Sci. Geol., 44, 73-86.

Kaljo, D. \& Martma, T. 2005. Ordovician and Silurian carbon isotope stratigraphy of western Baltica: a state of art report. In The Sixth Baltic Stratigraphical Conference, August 23-25, St. Petersburg, Russia. Abstracts (Koren, T., Evdokimova, I. \& Tolmacheva, T., eds), pp. 48-49. VSEGEI, St. Petersburg State University, St. Petersburg.

Kaljo, D., Rõõmusoks, A. \& Männil, R. 1958. On the Series of the Baltic Ordovician and their significance. Eesti NSV Tead. Akad. Toim. Füüs. Matem. Tehn.-tead. Seeria, 7, 71-73.

Kaljo, D., Hints, L., Hints, O., Martma, T. \& Nõlvak, J. 1999. Carbon isotope excursions and coeval biotic-environmental changes in the late Caradoc and Ashgill of Estonia. In Quo vadis Ordovician? (Kraft, P. \& Fatka, O., eds). Acta Univ. Carolinae Geol., 43, 507-510.

Kaljo, D., Hints, L., Martma, T., Nõlvak, J. \& Oraspõld, A. 2004. Late Ordovician carbon isotope trend in Estonia, its significance in stratigraphy and environmental analysis. Palaeogeogr. Palaeoclimatol. Palaeoecol., 210, 165-185.

Luha, A. 1940. Eesti. Geoloogiline koostis. Eesti entsüklopeedia. Täiendusköide. Tartu, 218-221.

Männik, P. 1992. Upper Ordovician and Lower Silurian Conodonts in Estonia. Doctoral Thesis. University of Tartu, Tartu.

Männik, P. 2001. Distribution of conodonts. In Valga (10) Drill Core (Põldvere, A., ed.). Estonian Geol. Sections, 3, 10-12.

Männik, P. 2003. Distribution of conodonts. In Ruhnu (500) Drill Core (Põldvere, A., ed.). Estonian Geol. Sections, 5, 17-23.

Männik, P. 2004. Recognition of the Mid-Caradoc Event in the conodont sequence of Estonia. In WOGOGOB-2004 Conference Materials (Hints, O. \& Ainsaar, L., eds), pp. 63-64. Tartu University Press. 
Männik, P. \& Viira, V. 2005. Distribution of Ordovician conodonts. In Mehikoorma (421) Drill Core (Põldvere, A., ed.). Estonian Geol. Sections, 6, 16-20.

Männil, R. 1958. Grundzüge der Stratigraphie der Keila-Stufe (Ordovizium, Estland). Eesti NSV Tead. Akad. Toim. Fü̈̈s. Matem. Tehn.-tead. Seeria, 7, 235-246 (in Russian).

Männil, R. 1966. Evolution of the Baltic Basin During the Ordovician. Valgus, Tallinn (in Russian).

Männil, R. 1976. Distribution of graptoloids in the Ordovician carbonate rocks of the East Baltic area. In Graptolites and Stratigraphy (Kaljo, D. \& Koren, T., eds), pp. 105-118. Academy of Sciences of the Estonian SSR, Institute of Geology, Tallinn (in Russian with English summary).

Männil, R. 1987. Explanatory text to the stratigraphic chart of Ordovician deposits. In Resheniya mezhvedomstvennogo stratigraficheskogo soveshchaniya po ordoviku i siluru VostochnoEvropejskoj platformy $1984 \mathrm{~g}$ s regional'nymi stratigraficheskimi skhemami (Kaljo, D. L., ed.), pp. 17-46. VSEGEI, Leningrad (in Russian).

Männil, R. 1990. The Ordovician of Estonia. In Field Meeting Estonia. An Excursion Guidebook (Kaljo, D. \& Nestor, H., eds), pp. 11-20. Institute of Geology, Estonian Academy of Sciences, Tallinn.

Männil, R. \& Meidla, T. 1994. The Ordovician System of East European Platform. IUGS Publ., 28, $1-52$.

Martma, T. 2005. Ordovician carbon isotopes. In Mehikoorma (421) Drill Core (Põldvere, A., ed.). Estonian Geol. Sections, 6, 25-27.

Meidla, T. \& Ainsaar, L. 2004. On the Ordovician System in Estonia. In WOGOGOB-2004 Conference Materials (Hints, O. \& Ainsaar, L., eds), pp. 107-111. Tartu University Press.

Meidla, T. 1996. Late Ordovician ostracodes of Estonia. Fossilia Baltica, 2, Tartu.

Nielsen, A. T., Harper, D. A. T. \& Stouge, S. S. 2004. A revised chronostratigraphic scheme for the Ordovician of Baltoscandia: potential for trans Baltoscandian correlation. In WOGOGOB2004 Conference Materials (Hints, O. \& Ainsaar, L., eds), pp. 75-76. Tartu University Press.

Nõlvak, J. 1997. Ordovician. Introduction. In Geology and Mineral Resources of Estonia (Raukas, A. \& Teedumäe, A., eds), pp. 52-55. Estonian Academy Publishers, Tallinn.

Nõlvak, J. 1999. Ordovician chitinozoan biozonation of Baltoscandia. In Quo vadis Ordovician? (Kraft, P. \& Fatka, O., eds). Acta Univ. Carolinae Geol., 43, 287-290.

Nõlvak, J. 2001. Distribution of chitinozoans. In Valga (10) Drill Core (Põldvere, A., ed.). Estonian Geol. Sections, 3, 8-10.

Nõlvak, J. 2002. Chitinozoan Biostratigraphy in the Ordovician of Baltoscandia. Doctoral Thesis. Tallinn Technical University, Tallinn.

Nõlvak, J. 2005. Distribution of Ordovician chitinozoans. In Mehikoorma (421) Drill Core (Põldvere, A., ed.). Estonian Geol. Sections, 6, 20-22.

Nõlvak, J. \& Goldman, D. 2004. Distribution of Nemagraptus in the East Baltic Ordovician. In WOGOGOB-2004 Conference Materials (Hints, O. \& Ainsaar, L., eds), pp. 75-76. Tartu University Press.

Nõlvak, J. \& Grahn, Y. 1993. Ordovician chitinozoan zones from Baltoscandia. Rev. Palaeobot. Palynol., 79, 245-269.

Paris, F., Grahn, Y., Nestor, V. \& Lakova, I. 1999. A revised chitinozoan classification. J. Paleontol., 74, 549-570.

Põlma, L., Sarv, L. \& Hints, L. 1988. Lithology and Fauna of the Caradoc Series Type Sections in North Estonia. Valgus, Tallinn (in Russian).

Puura, I. \& Viira, V. 1999. Chronostratigraphy of the Cambrian-Ordovician boundary beds in Baltoscandia. In Quo vadis Ordovician? (Kraft, P. \& Fatka, O., eds). Acta Univ. Carolinae Geol., 43, 5-8.

Puura, I. \& Viira, V. 2004. Tracing the base of the Ordovician System in Baltoscandia. In WOGOGOB-2004 Conference Materials (Hints, O. \& Ainsaar, L., eds), pp. 85-86. Tartu University Press. 
Rõõmusoks, A. 1956. Biostratigraphical subdivision of the Ordovician of the Estonian SSR. ENSV Tead. Akad. Geol. Inst. Uurimused, 1, 9-29 (in Russian).

Salzman, M. R., Bergström, S. M., Huff, W. D. \& Kolata, D. R. 2003. Conodont and graptolite biostratigraphy and the Ordovician (Early Chatfieldian, Middle Caradocian) $\delta^{13} \mathrm{C}$ excursion in North America and Baltoscandia: implications for the interpretation of the relations between the Millbrig and Kinnekulle K-bentonites. In Ordovician from the Andes (Albanesi, G. L., Beresi, M. S. \& Peralta, S. H., eds). INSUGEO Ser. Correl. Geol., 17, $137-142$.

Viira, V. 1974. Ordovician Conodonts of the East Baltic. Valgus, Tallinn (in Russian).

Viira, V., Löfgren, A., Mägi, S. \& Wickström, J. 2001. An Early to Middle Ordovician succession of conodont faunas at Mäekalda, northern Estonia. Geol. Mag., 138, 699-718.

Viira, V., Aldridge, R. J. \& Curtis, S. 2006. Conodonts of the Kiviõli Member, Viivikonna Formation (Upper Ordovician) in the Kohtla section, Estonia. Proc. Estonian Acad. Sci. Geol., 55 (in press).

Webby, B. D., Cooper, R. A., Bergström, S. M. \& Paris, F. 2004. Stratigraphic framework and time slices. In The Great Ordovician Biodiversification Event (Webby, B. D., Paris, F., Droser, M. L. \& Percival, I. G., eds), pp. 41-47. Columbia University Press, New York.

\section{Eesti Ordoviitsiumi ajaskaala: uuemad andmed}

\section{Jaak Nõlvak, Olle Hints ja Peep Männik}

Ordoviitsiumi geoloogia ja stratigraafia uurimine on Eestis kestnud enam kui 150 aastat, mille tulemuseks on üks detailsemaid Ordoviitsiumi ajaskaalasid maailmas. Artiklis on esitatud uuendatud Eesti Ordoviitsiumi ajaskaala, selle korrelatsioon rahvusvahelise standardiga ja graptoliitide, kitiinikute ning konodontide täiendatud ja kommenteeritud biotsonaalsed skeemid. On diskuteeritud alamladestikulise liigestuse küsimuste üle ja tehtud ettepanek nimetada Viru ladestiku ülemine alamladestik Vinni puurläbilõike järgi Vinni alamladestikuks ning Harju ladestiku ülemine alamladestik Atla jõe järgi Atla alamladestikuks. 